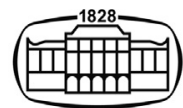

AKADÉMIAI KIADÓ

European Journal of Microbiology and Immunology

10 (2020) 3, 147-155

DOI:

$10.1556 / 1886.2020 .00015$

(c) 2020 The Author(s)

ORIGINAL RESEARCH

PAPER

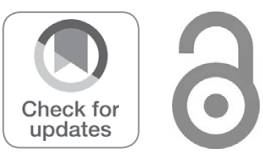

\title{
Surveillance of enteropathogenic bacteria, protozoa and helminths in travellers returning from the tropics
}

\author{
DOROTHEA WIEMER ${ }^{1 *}$, NORBERT GEORG SCHWARZ ${ }^{2}$, \\ GERD-DIETER BURCHARD ${ }^{2}$, HAGEN FRICKMANN ${ }^{1,3} \odot$, \\ ULRIKE LODERSTAEDT $^{2}$ and RALF-MATTHIAS HAGEN ${ }^{4}$
}

\footnotetext{
${ }^{1}$ Department of Tropical Medicine at the Bernhard Nocht Institute, Bundeswehr Hospital Hamburg, Hamburg, Germany

2 Bernhard Nocht Institute for Tropical Medicine, Hamburg, Germany

${ }^{3}$ Institute for Microbiology, Virology and Hygiene, University Medicine Rostock, Rostock, Germany

${ }^{4}$ Department for Microbiology and Hospital Hygiene, Bundeswehr Central Hospital Koblenz, Koblenz, Germany
}

Received: June 29, $2020 \bullet$ Accepted: July 11, 2020

Published online: September 9, 2020

\begin{abstract}
Diarrhoea is a frequent symptom associated with travelling to tropical regions, but the cause is often not found. Epidemiology was assessed including up-to-date real-time PCR approaches.

We analysed datasets of 528 patients who presented at the Bernhard Nocht Institute for Tropical Medicine in Hamburg, Germany, between 2006 and 2010 for screening purposes or because of diarrhoea. Stool samples were obtained and investigated by microscopy, bacterial culture, two PCR assays targeting Entamoeba histolytica, Entamoeba dispar, Giardia duodenalis, and Cryptosporidium parvum, or Salmonella spp., Shigella/EIEC spp., Campylobacter jejuni, and Yersinia spp.

Among patients with gastrointestinal symptoms, 51\% tested positive for bacteria or parasites, of which $66 \%$ had a known enteropathogenic potential. In patients without diarrhoea, $53 \%(n=80)$ were positive, and $33 \%$ of these cases harboured agents of pathogenic potential. Association with clinical symptoms was primarily found for bacterial infections. Blastocystis hominis, however, was more frequent in asymptomatic than in symptomatic travellers.

In conclusion, the study stresses the etiological relevance of bacterial gastroenteritis in travellers returning from the tropics, the need for molecular approaches to increase diagnostic sensitivity and demonstrates that asymptomatic carriage of enteropathogens after prolonged stays in the tropics is similarly frequent compared with symptomatic infections in travellers.
\end{abstract}

\section{KEYWORDS}

tropical epidemiology, travellers, gastrointestinal infection, enteropathogenic bacteria, enteric protozoa, realtime PCR, returnee screening

\footnotetext{
*Corresponding author. Department of Tropical Medicine at the Bernhard Nocht Institute, Bundeswehr Hospital Hamburg, Bernhard-Nocht Str. 74, 20359 Hamburg, Germany.

E-mail: wiemer@bni-hamburg.de Tel.: +49 406947 2840; fax: +494069472859
}

\section{INTRODUCTION}

According to the GeoSentinel surveillance system of the International Society of Travel Medicine, approximately one third (34.5\%) of all travellers presenting to GeoSentinel sites between 2007 and 2011 complained about gastrointestinal symptoms [1]. The numbers vary from $15 \%$ [2] up to $70 \%$ [3] depending on the travel destination, the season or how the gastrointestinal symptoms were classified. Overall, the incidence seems to decline in the last two decades [4].

Usually, three or more watery stools per day and at least one accompanying symptom in direct correlation to a travel abroad are called traveller's diarrhoea. This condition is self- 
limiting in the immunocompetent patient [5]. In up to $3 \%$ of the travellers, however, it progresses from acute to persistent or chronic diarrhoea [6]. Apart from insufficiently treated bacterial infections, parasites like Giardia duodenalis may cause chronic diarrhoea. But it can also occur as sequelae of prior infection like the post-infectious irritable bowel syndrome (PI-IBS) or due to other underlying diseases which become unmasked [6]. Most of the cases, however, remain unresolved in terms of aetiology [7,8], especially when patients' symptoms do not fulfil the strict case definitions of traveller's diarrhoea.

The role of diagnostic detections of facultatively pathogenic microorganisms, which do not unambiguously fulfil the Henle-Koch postulates, for the specificity of case definitions of infectious diseases is an issue of ongoing academic debate $[9,10]$. The problem is especially pronounced if sensitivity and specificity limitations of diagnostic approaches makes the validity of laboratory diagnostic results doubtful [11]. Especially in high endemicity settings, molecular detections of facultatively pathogenic microorganisms occur in symptomatic and asymptomatic patients in similar frequencies [12] and high colonization rates can even be found in completely asymptomatic individuals [13], making semi-immunity-phenomena likely. In non-endemicity settings like Germany and Switzerland, however, studies applying PCR for gastrointestinal pathogens rarely detect multiple pathogens and suggest acceptable correlation of pathogen detections with present or previous gastrointestinal symptoms $[14,15]$.

In the present study, we aimed at assessing whether and in how far the use of PCR methods can help to find a diagnosis in a heterogeneous population of patients complaining about subjectively perceived diarrhoea at the time of presentation, and to relate their symptoms to a travel abroad, and at comparing the results with a group of returning travellers not complaining about diarrhoea.

\section{MATERIALS AND METHODS}

\section{Study population}

From 528 patients that presented at the outpatient department of the Bernhard Nocht Institute for Tropical Medicine in Hamburg, Germany, between 2006 and 2010, stool samples had been recovered and from these DNA had been extracted and stored. We retrospectively analysed the corresponding case files.

\section{Diagnostic workflow}

Merthiolate-formaldehyde fixed stool samples $(n=528)$ were examined microscopically for parasites and helminth eggs after ether concentration and iodine - staining [16].

Depending on the clinical presentation, non-fixed stool samples $(n=213)$ were also routinely microbiologically tested at the University Medical Centre Hamburg-Eppendorf according to the local standard operating procedures for microbiological stool diagnostics.
From fresh native stool samples of all patients, DNA was isolated using the QIAamp ${ }^{\circledR}$ DNA Stool Mini Kit (Qiagen, Hilden, Germany) according to the manufacturer's instructions. In-house PCR for the enteropathogenic protozoa Entamoeba histolytica, G. duodenalis, Cryptosporidium spp. and commensal Entamoeba dispar [17-22] was done using protocols established for routine diagnostic analyses by the German National Reference Centre for Tropical Diseases at the Bernhard Nocht Institute, Hamburg.

The remaining DNA samples $(n=478)$ were stored at $-80{ }^{\circ} \mathrm{C}$.

With this DNA, a second in-house PCR test that targets the invasive enteropathogenic bacteria Salmonella spp., Shigella spp./enteroinvasive Escherichia coli (EIEC), Campylobacter jejuni and Yersinia spp. was performed. The diagnostic reliability of this procedure has been shown previously in comparison with cultural approaches $[14,23]$.

\section{Patient data}

The patients' data belonging to the samples were collected, but with exception of age, sex and nationality, no further personal data were recorded for the study to ensure the participants' privacy. We noted the presence or absence of symptoms (diarrhoea, stool numbers of $\geq 3$ per day, bloody stool, nausea and vomiting, abdominal pain, cramps, strong meteorism and fever, either just felt or measured) as well as the time of the beginning of symptoms, and data concerning their stay abroad (country, duration, type of travel).

\section{Statistics}

Patients actually complaining of diarrhoea, according to the assessment of the physician in the case file, were included in the study group. The control group comprised patients who did not report diarrhoea at the time of presentation and who were screened for enteropathogenic agents for other reasons, e.g. after a long term stay in the tropics. The datasets were analysed using Stata Version 14 (StataCorp, College Station, Texas, USA).

\section{Ethics}

The project was approved by the ethics commission of the Medical Doctor's Association of Hamburg, Germany (No. WF-040/15). There were no ethical concerns against the anonymous retrospective assessment.

\section{RESULTS}

\section{Description of the collective}

The gender distribution was equal; $49 \%$ men $(n=256)$ and $51 \%$ women $(n=272)$ aged from 6 years to 73 years (median 35 years $)$ were assessed. $23 \%(n=123)$ were foreign residents.

The duration of the previous journey or stay in the tropics varied from 2 days to more than 5 years (median 30 days in a left-shifted distribution). The period after returning 
Table 1. Descriptive data of the patient cohort

\begin{tabular}{|c|c|c|c|}
\hline & $\begin{array}{c}\text { All patients } \\
N=528(\% \text { of all })\end{array}$ & $\begin{array}{l}\text { Patients with Diarrhoea (pwd) } \\
\quad N=344(\% \text { of pwd) }\end{array}$ & $\begin{array}{l}\text { Patients without diarrhoea (pwod) } \\
\quad N=184 \text { (\% of pwod) }\end{array}$ \\
\hline \multicolumn{4}{|l|}{$\operatorname{Sex}$} \\
\hline Male & $256(48 \%)$ & $153(44 \%)$ & $103(56 \%)$ \\
\hline Female & $272(52 \%)$ & $191(56 \%)$ & $81(44 \%)$ \\
\hline \multicolumn{4}{|l|}{ Nationality } \\
\hline German & $405(77 \%)$ & $277(81 \%)$ & $128(70 \%)$ \\
\hline Others & $123(23 \%)$ & $67(19 \%)$ & $56(30 \%)$ \\
\hline \multicolumn{4}{|l|}{ Age (Median 36 years) } \\
\hline$<5 \mathrm{y}$ & $0(0 \%)$ & $0(0 \%)$ & $0(0 \%)$ \\
\hline$<10 y$ & $2(0 \%)$ & $2(1 \%)$ & $0(0 \%)$ \\
\hline $10-19 y$ & $34(6 \%)$ & $25(7 \%)$ & $9(5 \%)$ \\
\hline $20-29 y$ & $140(27 \%)$ & $108(31 \%)$ & $32(17 \%)$ \\
\hline $30-39 y$ & $142(27 \%)$ & $84(24 \%)$ & $58(32 \%)$ \\
\hline $40-49 y$ & $85(16 \%)$ & $51(15 \%)$ & $34(18 \%)$ \\
\hline $50-59 y$ & $78(15 \%)$ & $51(15 \%)$ & $27(15 \%)$ \\
\hline $60-69 y$ & $44(8 \%)$ & $23(7 \%)$ & $21(11 \%)$ \\
\hline$>70 \mathrm{y}$ & $3(1 \%)$ & $0(0 \%)$ & $3(2 \%)$ \\
\hline \multicolumn{4}{|l|}{ Travel time (Median 30 days) } \\
\hline$\leq 7$ days & $14(3 \%)$ & $13(4 \%)$ & $1(1 \%)$ \\
\hline$\leq 14$ days & $44(8 \%)$ & $41(12 \%)$ & $3(2 \%)$ \\
\hline$\leq 21$ days & $40(8 \%)$ & $37(11 \%)$ & $3(2 \%)$ \\
\hline$\leq 1$ month & $81(15 \%)$ & $77(22 \%)$ & $4(2 \%)$ \\
\hline$\leq 3$ months & $76(14 \%)$ & $55(16 \%)$ & $21(11 \%)$ \\
\hline$\leq 6$ months & $40(8 \%)$ & $33(10 \%)$ & $7(4 \%)$ \\
\hline$\leq 1$ year & $46(9 \%)$ & $26(8 \%)$ & $20(11 \%)$ \\
\hline$\leq 5$ years & $32(6 \%)$ & $15(4 \%)$ & $17(9 \%)$ \\
\hline$>5$ years & $18(3 \%)$ & $4(1 \%)$ & $14(8 \%)$ \\
\hline No data & $137(26 \%)$ & $43(13 \%)$ & $94(51 \%)$ \\
\hline \multicolumn{4}{|l|}{ Travel region } \\
\hline Western Asia & $20(4 \%)$ & $12(3 \%)$ & $8(4 \%)$ \\
\hline Central Asia & $6(1 \%)$ & $3(1 \%)$ & $3(2 \%)$ \\
\hline Eastern Asia & $13(2 \%)$ & $12(3 \%)$ & $1(1 \%)$ \\
\hline South Eastern Asia & $71(13 \%)$ & $49(14 \%)$ & $22(12 \%)$ \\
\hline \multirow[t]{2}{*}{ Southern Asia } & $102(19 \%)$ & $86(25 \%)$ & $16(9 \%)$ \\
\hline & $82(16 \%)$ & $70(20 \%)$ & $12(7 \%)$ \\
\hline \multicolumn{4}{|l|}{ - India } \\
\hline \multirow[t]{2}{*}{ Northern Africa } & $45(9 \%)$ & $32(9 \%)$ & $13(7 \%)$ \\
\hline & $30(6 \%)$ & $22(6 \%)$ & $8(4 \%)$ \\
\hline \multicolumn{4}{|l|}{ - Egypt } \\
\hline Western Africa & $64(12 \%)$ & $28(8 \%)$ & $36(20 \%)$ \\
\hline Eastern Africa & $41(8 \%)$ & $23(7 \%)$ & $18(10 \%$ \\
\hline Central Africa & $10(2 \%)$ & $6(2 \%)$ & $4(2 \%)$ \\
\hline Southern Africa & $18(3 \%)$ & $12(3 \%)$ & $6(3 \%)$ \\
\hline Oceania & $7(1 \%)$ & $4(1 \%)$ & $3(2 \%)$ \\
\hline Central America \& Caribbean & $44(8 \%)$ & $35(10 \%)$ & $9(5 \%)$ \\
\hline South America & $42(8 \%)$ & $30(9 \%)$ & $12(7 \%)$ \\
\hline Europe & $10(2 \%)$ & $1(0 \%)$ & $9(5 \%)$ \\
\hline Miscellaneous & $7(1 \%)$ & $2(1 \%)$ & $5(3 \%)$ \\
\hline No data & $36(7 \%)$ & $9(3 \%)$ & $27(15 \%)$ \\
\hline \multicolumn{4}{|l|}{ Type of travel } \\
\hline Business & $41(8 \%)$ & $27(8 \%)$ & $14(8 \%)$ \\
\hline Tourism & $272(52 \%)$ & $216(63 \%)$ & $56(30 \%)$ \\
\hline VFR (visiting friends and relatives) & $35(7 \%)$ & $11(3 \%)$ & $24(13 \%)$ \\
\hline Long term & $125(24 \%)$ & $75(22 \%)$ & $50(27 \%)$ \\
\hline Immigrant & $9(2 \%)$ & $4(1 \%)$ & $5(3 \%)$ \\
\hline Backpacker & $6(1 \%)$ & $5(1 \%)$ & $1(1 \%)$ \\
\hline No data & $39(7 \%)$ & $6(2 \%)$ & $33(18 \%)$ \\
\hline
\end{tabular}


Table 1. Continued

\begin{tabular}{|c|c|c|c|}
\hline & $\begin{array}{c}\text { All patients } \\
N=528(\% \text { of all })\end{array}$ & $\begin{array}{l}\text { Patients with Diarrhoea (pwd) } \\
\quad N=344 \text { (\% of pwd) }\end{array}$ & $\begin{array}{l}\text { Patients without diarrhoea (pwod) } \\
\qquad N=184 \text { (\% of pwod) }\end{array}$ \\
\hline \multicolumn{4}{|l|}{ Start of Symptoms (any) } \\
\hline Before the last travel & $13(2 \%)$ & $5(1 \%)$ & $8(4 \%)$ \\
\hline During the last travel & $292(55 \%)$ & $239(69 \%)$ & $53(29 \%)$ \\
\hline After the travel & $128(24 \%)$ & $83(24 \%)$ & $45(24 \%)$ \\
\hline No data & $95(18 \%)$ & $17(5 \%)$ & $52(28 \%)$ \\
\hline
\end{tabular}

from the tropics until presentation at the outpatient department also varied from the day of arrival to several years after exposition (median 33 days in a left-shifted distribution). Travel destinations were evenly distributed throughout the whole world with $26 \%$ in sub-Saharan Africa, $20 \%$ in South Asia, $17 \%$ in South East Asia, 16\% in Central and South America, and 21\% in miscellaneous places. Descriptive data extracted from the files are shown in Table 1.

In travellers to South-Asia (mainly India), especially protozoa could be found in the stool samples. Also, the frequency of bacteria detected was higher than in other travel destinations (Fig. 1).

Three hundred forty-four patients presented because of diarrhoea (patient with diarrhoea $=$ pwd). 7 of them suffered from diarrhoea only. The remaining patients reported additional symptoms as well. Only 25 patients fulfilled the complete definition of traveller's diarrhoea with more than 3 watery stools per day and an additional symptom. All the rest had less frequent stools and, notwithstanding changed stool consistency and symptoms of various degrees, 103 of the pwd reported fever (Table 2).

More than half of the pwd (66\%) presented themselves at the outpatient clinic within 12 weeks. From the patients without diarrhoea ( $=$ pwod) $(n=184), 52 \%$ visited the outpatient clinic within 6 months (Fig. 2). The duration of travel was 7 times shorter for pwd (median 30 days) than for pwod (median 210 days), although the number of travellers classified as long-term travellers was comparable (pwd $n=$ 55; pwod $n=47$ ).

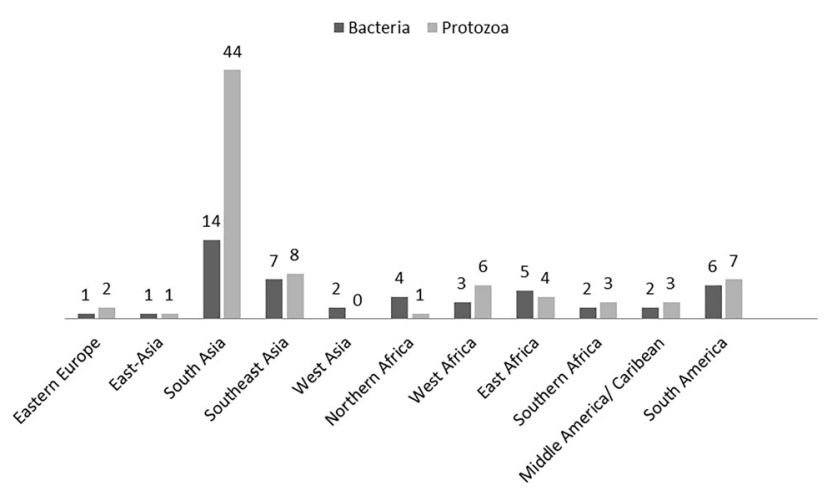

Fig. 1. Detections of bacteria and protozoa distributed by travel destination. The height of the bars correspondents to the number of detections which are also indicated by absolute numbers on top of the bars
Of the pwd, $51 \%(n=175)$ tested positive for bacteria or parasites. $66 \%(n=116)$ of the detected pathogens had a known enteropathogenic potential, i.e. a potentially causative pathogen could be found in $34 \%$ of the patients with diarrhoea. Among the pwod, 53\% $(n=99)$ tested positive for bacteria or protozoa and 33\% $(n=33)$ of these cases comprised pathogens with a known pathogenic potential. This means that in $17 \%$ of the pwod, a pathogenic bacterium or protozoan could be found in faeces.

\section{Pathogens}

Microscopic stool examination detected protozoa in $40.3 \%$ (213 of 528 examined stools), 38\% $(n=201)$ of these were of possible enteropathogenic potential (E. histolytica/dispar $n=24$, G. duodenalis $n=28$, Blastocystis hominis $n=149$ ). In 6 pwod, helminth eggs were found (Ancylostoma duodenale $n=2$, Schistosoma mansoni $n=1$, Ascaris lumbricoides $n=3$ ). Dientamoeba fragilis was observed in nine cases ( $n=4$ in pwod, $n=5$ in pwd).

Bacterial culture was done in 255 samples. 16 of these were positive (Staphylococcus aureus $n=3$ ( 3 pwd), Bacillus spp. $n=1$ ( 1 pwd), Clostridoides difficile $n=2$ ( 1 pwd, 1 pwod), E. coli $n=3$ (3 pwd), E. coli in combination with $S$. aureus $n=1$ (pwd), Klebsiella spp. $n=2$ ( $2 \mathrm{pwd})$, Pseudomonas aeruginosa $n=1$ (1 pwd), Shigella sonnei $n=1$ (1 pwd), Shigella flexneri $n=1$ (1 pwd), Salmonella spp. $n=1$ $(1 \mathrm{pwd}))$. Pathogens that are not typically detected in stool diagnostics for diarrhoea, such as Staphylococci, Klebsiellae or Pseudomonas, were registered if they were the predominant germs or if they indicated a clear miscolonisation.

\section{PCR}

All 528 patients underwent PCR testing for 4 parasite species. $15.3 \%(n=81)$ were positive: For $G$. duodenalis $7.0 \%$ $(n=37)$, for E. histolytica $0.8 \%(n=4)$, for E. dispar $7.2 \%$ $(n=38)$, and for Cryptosporidium parvum $0.4 \%(n=2)$.

For the comparison of microscopy and PCR, we focused on G. duodenalis, E. histolytica and C. parvum, because these are protozoa of assured pathogenic potential. Results are shown in Table 3.

In comparison to microscopy $(n=24), 13$ additional cases of $G$. duodenalis infection were detected by PCR. Three times, protozoa identified as G. duodenalis went undetected by PCR. Among 34 amebae classified as undistinguishable (E. histolytica/dispar cysts or trophozoites) by microscopy, 4 were confirmed by PCR as E. histolytica while 22 apparently microscopically identified $E$. histolytica remained negative in 
Table 2. Synopsis of symptoms

\begin{tabular}{|c|c|c|c|}
\hline $\begin{array}{l}\text { Diarrhoea } \\
N=344 \\
(65 \%)\end{array}$ & $\begin{array}{c}\text { All patients (\% } \\
\text { of all with this } \\
\text { symptom) }\end{array}$ & $\begin{array}{c}\text { Male (\% of } \\
\text { all with this } \\
\text { symptom) } \\
N=153 \\
(44 \%)\end{array}$ & $\begin{array}{c}\text { Female (\% of } \\
\text { all with this } \\
\text { symptom) } \\
N=191 \\
(56 \%)\end{array}$ \\
\hline $\begin{array}{l}\geq 3 \text { stools per } \\
\text { day }\end{array}$ & $32(9 \%)$ & $13(41 \%)$ & $19(56 \%)$ \\
\hline \multicolumn{4}{|l|}{$\begin{array}{l}\text { Median } 4 \text { per } \\
\text { day }\end{array}$} \\
\hline Bloody stool & $50(15 \%)$ & $24(48 \%)$ & $26(59 \%)$ \\
\hline $\begin{array}{c}\text { Nausea and } \\
\text { vomiting }\end{array}$ & $119(35 \%)$ & $36(30 \%)$ & $83(70 \%)$ \\
\hline $\begin{array}{l}\text { Abdominal } \\
\text { pain }\end{array}$ & $113(39 \%)$ & $44(39 \%)$ & $69(61 \%)$ \\
\hline Cramps & $56(16 \%)$ & $28(50 \%)$ & $28(50 \%)$ \\
\hline Meteorism & $107(31 \%)$ & $60(56 \%)$ & 47 (44\%) \\
\hline Fever & $103(30 \%)$ & $50(49 \%)$ & $51(51 \%)$ \\
\hline Fever $>39^{\circ} \mathrm{C}$ : & $32(9 \%)$ & & \\
\hline $\begin{array}{l}\text { No Diarrhoea } \\
N=184 \\
(35 \%)\end{array}$ & $\begin{array}{c}\text { All patients (\% } \\
\text { of all with this } \\
\text { symptom) }\end{array}$ & $\begin{array}{c}\text { Male (\% of all } \\
\text { with this } \\
\text { symptom) } \\
N=103 \\
(56 \%)\end{array}$ & $\begin{array}{c}\text { Female (\% of } \\
\text { all with this } \\
\text { symptom) } \\
N=81(44 \%)\end{array}$ \\
\hline Fever & $6(3 \%)$ & $3(50 \%)$ & $3(50 \%)$ \\
\hline Meteorism & $2(1 \%)$ & $2(100 \%)$ & $0(0 \%)$ \\
\hline $\begin{array}{l}\text { Abdominal } \\
\text { pain }\end{array}$ & $6(3 \%)$ & $2(33 \%)$ & $4(67 \%)$ \\
\hline $\begin{array}{c}\text { Nausea and } \\
\text { vomiting }\end{array}$ & $3(2 \%)$ & $2(67 \%)$ & $1(33 \%)$ \\
\hline
\end{tabular}

PCR. C. parvum was not identified via microscopy at all, but only by PCR. Table 4 shows the cross-tabulation of stool PCR and stool culture for the 4 protozoa G. duodenalis, E. histolytica, C. parvum, and E. dispar.

Of 478 individuals who underwent PCR testing for bacteria, $7.5 \%(n=36)$ were positive for one of the 4 bacterial enteropathogenic target organisms included in the multiplex PCR. For Salmonella spp. $4(0.8 \%)$ were positive, for Shigella spp./EIEC 20 (4.2\%), for Campylobacter spp. 15 (3.1\%), and for Yersinia spp. none. In three individuals, double infections were seen (Table 5). When comparing the results of stool PCR to stool culture, we focused on those for which stool culture and bacterial PCR were available and we could only compare bacteria for which specifically binding oligonucleotides were included in the PCR reaction. Table 6 shows the cross-tabulation of stool PCR and stool culture for these 4 enteropathogenic bacterial target organisms that was done with the 213 included results.

Irrespective of the pathogenicity, the prevalence of protozoa $(42.8 \%)$ in the whole study group was four times higher than the prevalence of bacteria (10\%).

\section{Association with symptoms}

The number of positive results for bacterial pathogens was more than six times higher in pwd $(42 / 299,8.7 \%)$ compared to powd $(6 / 179,1.2 \%)$; with Shigella spp./EIEC and Campylobacter spp. being the most frequent ones (Table 3).

Fever was also associated with a positive result for bacteria in stool culture as well as by PCR. Of 383 individuals without fever, only $18(4.6 \%)$ had a positive stool PCR for bacteria in comparison to $22(23.1 \%)$ of those with fever $\left(n=95, \sum=\right.$ 478).

In 89 pwd with fever, 19 positive results for bacteria were found (Salmonella spp. $n=2$, Klebsiella spp. $n=1$, Shigella spp./EIEC $n=5$, Shigella spp./EIEC and Salmonella spp. $n=1$, Shigella spp./EIEC in combination with $C$. jejuni $n=1, C$. difficile $n=1, C$. jejuni $n=8$ ). But also 5 of the pwod $(n=173)$ without fever showed evidence of potentially pathogenic bacteria in their stool (C. difficile $n=1$, Shigella spp./EIE $n=3$, C. jejuni $n=1$ ).

There was no association between diarrhoea and detected protozoa (Table 3$)$. B. hominis was more frequent in pwod $(35.9 \%(n=66))$ than in pwd $(24.1 \%(n=83))$.

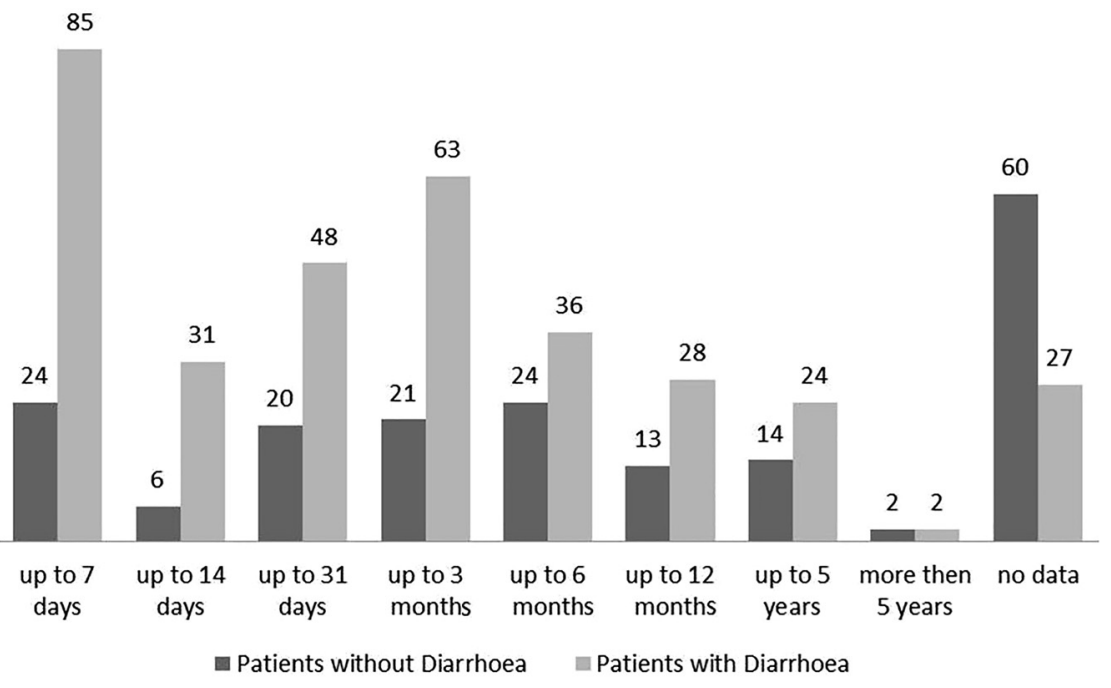

Fig. 2. Durations of travel of patients with and without diarrhoea. The height of the bars correspondents to the number of detections which are also indicated by absolute numbers on top of the bars 
Table 3. Diarrhoea and PCR result for protozoa $(N=528)$

\begin{tabular}{lcccc}
\hline N & $\begin{array}{c}\text { Diarrhoea } N=344 \\
\text { positive (\%) }\end{array}$ & $\begin{array}{c}\text { No diarrhoea } N=184 \\
\text { positive (\%) }\end{array}$ & $\begin{array}{c}\text { Number } \\
\text { positive }\end{array}$ & $\begin{array}{c}\text { Prevalence ratio diarrhoea vs. } \\
\text { no diarrhoea }(95 \% \text { CI) }\end{array}$ \\
\hline Giardia duodenalis & $27(7.9 \%)$ & $10(5.4 \%)$ & 37 & $1.44(0.71-2.92)$ \\
Entamoeba histolytica & $3(0.87 \%)$ & $1(0.54 \%)$ & 4 & $1.60(0.17-15.3)$ \\
Entamoeba dispar & $19(5.5 \%)$ & $19(10.3 \%)$ & 38 & $0.54(0.29-0.98)$ \\
Cryptosporidium parvum & $2(0.6 \%)$ & 0 & 2 & not assessable \\
Blastocystis hominis & $83(24.1 \%)$ & $66(35.9 \%)$ & 149 & $0.67(0.51-0.88)$ \\
$\quad$ Microscopy) & & & & \\
\hline
\end{tabular}

\section{DISCUSSION}

It is increasingly accepted that PCR methods contribute to the improvement of microbiological diagnostics and also provide additional information, for example on the aetiology of traveller's diarrhoea. The results of our study line up with previous findings [24-26], as the detection of enteropathogenic bacteria that are sensitive to pre-analytic and culture conditions, such as Shigella spp. and C. jejuni, is significantly increased when PCR is applied [14]. Accordingly, infections by these bacteria, in particular, were discovered in this study more frequently by PCR than by culture methods alone. A proportion of asymptomatic patients (3\%) in the study group harboured and potentially shed pathogenic bacteria in their stool, at least if no mere shedding of residual DNA after previously cleared infections was the reason for positive PCR signals.

For protozoa, the use of PCR methods could not increase the proportion of samples positive for any protozoon, but it differentiates and detects proven pathogenic agents like $E$. histolytica and G. duodenalis. There was a significant discrepancy between the microscopic recognition of Entamoeba cysts and PCR-based allocation to pathogenic $E$. histolytica. Since 1989, it is known that E. histolytica and $E$. dispar are two distinct but morphologically identical species [27]. With PCR techniques, they can be distinguished [28] and a ratio of non-pathogenic E. dispar to E. histolytica of 10:1 has been described [29]. In this study, the ratio was 6:1.

The results of our study once more confirm that in the assessment of potential causes for diarrhoea associated with a stay in the tropics, E. histolytica will be overrated and G. duodenalis will be underestimated if only microscopy is performed [28, 30, 31].

We also observed that infections with Yersinia spp., a cause of diarrhoea in temperate latitudes which is notifiable

Table 4. Cross tabulation of stool microscopy and stool PCR results for the 4 protozoa Giardia duodenalis, Entamoeba histolytica, Entamoeba dispar, and Cryptosporidium parvum

\begin{tabular}{lcc}
\hline \multirow{2}{*}{$\begin{array}{l}\text { PCR } \\
\text { Positive }(n=81)\end{array}$} & \multicolumn{2}{c}{ Microscopy } \\
\cline { 2 - 3 } Positive $(n=87)$ & Negative $(n=471)$ \\
\hline Negative $(n=477)$ & 35 & 29 \\
\hline
\end{tabular}

in Germany, do not seem to play a role as causative agents for diarrhoea in travellers returning form tropical countries, as they were not detected at all in the study group. This is consistent with prior findings [32]. Only $1 \%$ of the patients, exclusively asymptomatic ones, showed helminth eggs in stool. We presume therefore that frequent nematodes, like $A$. lumbricoides, Enterobius vermicularis, and Trichuris trichiura, are rarely to be taken into consideration as a cause of diarrhoea in adult travellers.

Traveller's diarrhoea has been defined as "the passage of three or more unformed stools per 24 hour period [6], with at least one passage accompanied by symptoms of nausea, vomiting, abdominal cramps or pain, fever or blood in stool" during or shortly after travel [33].

In our study population, this definition was fulfilled only by $9 \%$ of the symptomatic patients. This could be one reason why the proportion of pathogens detected in patients with diarrhoea (34\%) was lower than in other studies [7]. This assumption is supported by the results of Lääveri and colleagues [34], who, depending on the definition of traveller's diarrhoea, described varying detection rates for pathogens between 37 and $65 \%$.

Possibly even more important is the observation that at least one pathogen or protozoon could be found with almost the same frequency in the faeces of symptom-free travel returnees from the tropics, especially G. duodenalis. Soonawala et al. [35] reasons that "[The] Infection [with Giardia lamblia] is usually self-limiting and does not have long-term repercussions. Furthermore, the prevalence of asymptomatic G. lamblia infection in The Netherlands is comparable to the post-travel incidence in this study; therefore, routine screening of asymptomatic travellers for G. lamblia is not warranted". The average prevalence of $G$. duodenalis $[7,35,36]$ in asymptomatic travellers seems to be about $4 \%$, but depending on the travel destination, it may be distinctly higher [21]. The overall notification rate for G. duodenalis in Europe was 5.5 cases per 100,000 individuals in 2017 . $60 \%$ of the cases were domestically acquired. This implies that almost half of all G. duodenalis cases were acquired abroad. The ECDC (European Centre for Disease Prevention and Control) recommends screening of all human stool samples submitted for diagnostic testing, irrespective of travel history, for Giardia cysts to permit the accurate reporting of locally acquired cases [37]. In Germany, infections with G. duodenalis are notifiable and it is recommended to treat all infected, whether symptomatic or not, so they can no longer 
Table 5. Diarrhoea and PCR results for bacteria $(N=478)$

\begin{tabular}{|c|c|c|c|c|}
\hline$N=478$ & $\begin{array}{l}\text { Diarrhoea } N=299 \\
\text { positives (\%) }\end{array}$ & $\begin{array}{c}\text { No diarrhoea } N=179 \\
\text { positives }(\%)\end{array}$ & Number of positives & $\begin{array}{c}\text { Prevalence ratio of diarrhoea vs. no } \\
\text { diarrhoea }(95 \% \mathrm{CI})\end{array}$ \\
\hline Salmonella spp. ${ }^{\mathrm{a}, \mathrm{b}}$ & $3(1.0 \%)$ & $1(0.56 \%)$ & 4 & $1.80(0.19-17.1)$ \\
\hline Shigella spp./EIEC ${ }^{\mathrm{a}, \mathrm{c}}$ & $17(5.7 \%)$ & $3(1.7 \%)$ & 20 & $3.39(1.01-11.4)$ \\
\hline Campylobacter spp. & $13(4.4 \%)$ & $2(1.1 \%)$ & 15 & $3.89(0.89-17.05)$ \\
\hline Yersinia spp. & 0 & 0 & 0 & \\
\hline
\end{tabular}

${ }^{\mathrm{a} O n e}$ individual was co-infected with Salmonella spp. and Shigella spp./EIEC.

${ }^{\mathrm{b}}$ One individual was co-infected with Salmonella spp. and Campylobacter jejuni.

${ }^{c}$ One individual was co-infected with Shigella spp./EIEC and Campylobacter jejuni.

Table 6. Cross tabulation of stool culture and stool PCR results for the 4 enteropathogenic bacterial target organisms Salmonella spp., Shigella spp./EIEC, Campylobacter jejuni, and Yersinia spp.

\begin{tabular}{|c|c|}
\hline & Stool culture ${ }^{a}$ \\
\hline PCR & Negative $(n=207)$ \\
\hline
\end{tabular}

\begin{tabular}{llr}
\hline Positive $(n=25)$ & 5 & 20 \\
Negative $(n=188)$ & 1 & 187 \\
\hline
\end{tabular}

${ }^{\mathrm{a}} 12$ culture results were positive for bacteria but not detected by PCR.

act as a source of infection [38]. This supports, from our point of view, the idea of performing stool examination for protozoa as a standard procedure in travellers returning from the tropics, at least after an extended stay and when they return from selected regions like South-Asia, South America and West Africa.

In contrast to the findings by Gautret et al. [2], we did not see an age-dependent clustering of diarrhoea in travellers. There was also no significant association of diarrhoea with the reason of travel or its duration. There is statistical evidence that enteropathogenic bacteria cause gastrointestinal (GI) symptoms, especially fever, when detected. Since we did not address the presence of bacteria in blood, we cannot prove that fever is an indicator for a generalisation of the infection. GI symptoms and evidence of protozoa, esp. $B$. hominis, showed no correlation in contrast to other observations [39-41], so this study does not support B. hominis as a causative agent for acute or prolonged diarrhoea [42]. With more $(50.4 \%)$ of those patients without GI-symptoms being positive for protozoa in stool compared to those with GIsymptoms (38.7\%), looking only at the absolute numbers, one could even claim a protective association of protozoa regarding GI symptoms, though it probably reflects mainly the ability of protozoa for long-term shedding from asymptomatic carriers.

PCR-assays again proved to be highly sensitive compared to "traditional" microbiological methods like culture from a complex sample matrix like stool or microscopy. Nevertheless, it must be remembered that PCR can only detect those pathogens for which it is designed and this limited spectrum must be taken into account [43]. PCR methods cannot completely replace microscopy and culture, as the latter ones allow a more comprehensive view, albeit at the price of lower sensitivity and the higher workload caused by cultural growth. From our point of view, currently only the combination of microscopy, culture, and molecular biological techniques can lead to a comprehensive picture in terms of the diagnosis of traveller's diarrhoea.

Funding sources: No financial support was received for this study.

Authors' contribution: DW, GDB, UL, and RMH jointly planned the study. RMH performed the molecular diagnostic assessments. DW and NGS assessed the data and performed the statistic analysis. DW prepared the manuscript. All authors have jointly optimized and reviewed the manuscript.

Conflict of interest: Nothing to declare.

\section{ACKNOWLEDGEMENTS}

We gratefully thank the medical technical assistants from the laboratory of Professor E. Tannich for performing microscopy and multiplex PCR for enteropathogenic protozoa, the medical technical assistants, S. Priesnitz and A. Michel, for adding the results of the multiplex PCR for enteropathogenic bacteria in all samples and the medical documentation assistants, N. Lindenberg and S. Schlegel, for compiling the data of all patients in the study group.

\section{REFERENCES}

1. Leder K, Torresi J, Libman MD, Cramer JP, Castelli F, Schlagenhauf P, et al. GeoSentinel Surveillance Network. GeoSentinel surveillance of illness in returned travelers, 2007-2011. Ann Intern Med 2013;158: $456-68$.

2. Gautret P, Gaudart J, Leder K, Schwartz E, Castelli F, Lim PL, et al. GeoSentinel Surveillance Network. Travel-associated illness in older adults (>60 y). J Travel Med 2012;19:169-77. 
3. Connor BA. Travelers' diarrhea (The yellow book). 2015. Cited July 2020, Available from: Online link no longer available. Copy can be provided by the first author.

4. Steffen R, Hill DR, DuPont HL. Traveler's diarrhea: a clinical review. JAMA 2015;313:71-80.

5. DuPont HL. Acute infectious diarrhea in immunocompetent adults. N Engl J Med 2014;370:1532-40.

6. Ferrah N, Leder K, Gibney K. Review of the causes and management of chronic gastrointestinal symptoms in returned travellers referred to an Australian infectious diseases service. Aust Fam Physician 2016;45:333-9.

7. Paschke C, Apelt N, Fleischmann E, Perona P, Walentiny C, Löscher T, et al. Controlled study on enteropathogens in travellers returning from the tropics with and without diarrhoea. Clin Microbiol Infect 2011;17:1194-200.

8. Shah N, DuPont HL, Ramsey DJ. Global etiology of travelers' diarrhea: systematic review from 1973 to the present. Am J Trop Med Hyg 2009;80:609-14.

9. Hahn A, Meyer CG, Frickmann H. Impact of diagnostic methods on efficacy estimation - a proof-of-principle based on historical examples. Trop Med Int Health 2020;25:357-63.

10. Hahn A, Frickmann H, Zautner AE. Impact of case definitions on efficacy estimation in clinical trials-a proof-of-principle based on historical examples. Antibiotics (Basel) 2020;9:E379.

11. Hahn A, Podbielski A, Meyer T, Zautner AE, Loderstädt U, Schwarz NG, et al. On detection thresholds-a review on diagnostic approaches in the infectious disease laboratory and the interpretation of their results. Acta Trop 2020;205:105377.

12. Zautner AE, Groß U, Emele MF, Hagen RM, Frickmann H. More pathogenicity or just more pathogens?-On the interpretation problem of multiple pathogen detections with diagnostic multiplex assays. Front Microbiol 2017;8:1210.

13. Frickmann H, Schwarz NG, Rakotozandrindrainy R, May J, Hagen RM. PCR for enteric pathogens in high-prevalence settings. What does a positive signal tell us? Infect Dis (Lond) 2015;47:491-8.

14. Wiemer D, Loderstaedt U, von Wulffen H, Priesnitz S, Fischer M, Tannich E, et al. Real-time multiplex PCR for simultaneous detection of Campylobacter jejuni, Salmonella, Shigella and Yersinia species in fecal samples. Int J Med Microbiol 2011;301:577-84.

15. Beckmann C, Heininger U, Marti H, Hirsch HH. Gastrointestinal pathogens detected by multiplex nucleic acid amplification testing in stools of pediatric patients and patients returning from the tropics. Infection 2014;42:961-70.

16. Allen AV, Ridley DS. Further observations on the formol-ether concentration technique for faecal parasites. J Clin Pathol 1970;23: 545-6.

17. Verweij JJ, Laeijendecker D, Brienen EA, van Lieshout L, Polderman AM. Detection of Cyclospora cayetanensis in travellers returning from the tropics and subtropics using microscopy and real-time PCR. Int J Med Microbiol 2003;293:199-202.

18. Verweij JJ, Blangé RA, Templeton K, Schinkel J, Brienen EA, van Rooyen MA, et al. Simultaneous detection of Entamoeba histolytica, Giardia lamblia, and Cryptosporidium parvum in fecal samples by using multiplex real-time PCR. J Clin Microbiol 2004;42:1220-3.

19. Kebede A, Verweij JJ, Endeshaw T, Messele T, Tasew G, Petros B, et al. The use of real-time PCR to identify Entamoeba histolytica and E. dispar infections in prisoners and primary-school children in Ethiopia. Ann Trop Med Parasitol 2004;98:43-8.

20. Frickmann H, Schwarz NG, Wiemer DF, Fischer M, Tannich E, Scheid PL, et al. Food and drinking water hygiene and intestinal protozoa in deployed German soldiers. Eur J Microbiol Immunol (Bp) 2013;3:53-60.

21. Frickmann H, Warnke P, Frey C, Schmidt S, Janke C, Erkens K, et al. Surveillance of food- and smear-transmitted pathogens in European soldiers with diarrhea on deployment in the tropics: experience from the European Union Training Mission (EUTM) Mali. Biomed Res Int 2015;2015:573904.

22. Köller T, Hahn A, Altangerel E, Verweij JJ, Landt O, Kann S, et al. Comparison of commercial and in-house real-time PCR platforms for 15 parasites and microsporidia in human stool samples without a gold standard. Acta Trop 2020;207:105516.

23. Gutiérrez-Cisneros MJ, Cogollos R, López-Vélez R, MartínRabadán P, Martínez-Ruiz R, Subirats M, et al. Application of realtime PCR for the differentiation of Entamoeba histolytica and $E$. dispar in cyst-positive faecal samples from 130 immigrants living in Spain. Ann Trop Med Parasitol 2010;104:145-9.

24. Lääveri T, Antikainen J, Pakkanen SH, Kirveskari J, Kantele A. Prospective study of pathogens in asymptomatic travellers and those with diarrhoea: aetiological agents revisited. Clin Microbiol Infect 2016;22:535-41.

25. van Hattem JM, Arcilla MS, Grobusch MP, Bart A, Bootsma MC, van Genderen PJ, et al. Travel-related acquisition of diarrhoeagenic bacteria, enteral viruses and parasites in a prospective cohort of 98 Dutch travellers. Travel Med Infect Dis 2017;19:33-6.

26. Jiang ZD, DuPont HL. Etiology of travellers' diarrhea. J Travel Med 2017;24(suppl_1):S13-16.

27. Tannich E, Horstmann RD, Knobloch J, Arnold HH. Genomic DNA differences between pathogenic and nonpathogenic Entamoeba histolytica. Proc Natl Acad Sci U S A 1989;86: 5118-22.

28. Blessmann J, Buss H, Nu PA, Dinh BT, Ngo QT, Van AL, et al. Real-time PCR for detection and differentiation of Entamoeba histolytica and Entamoeba dispar in fecal samples. J Clin Microbiol 2002;40:4413-17.

29. Fotedar R, Stark D, Beebe N, Marriott D, Ellis J, Harkness J. Laboratory diagnostic techniques for Entamoeba species. Clin Microbiol Rev 2007;20:511-32.

30. Nazeer JT, El Sayed Khalifa K, von Thien H, El-Sibaei MM, AbdelHamid MY, Tawfik RA, et al. Use of multiplex real-time PCR for detection of common diarrhea causing protozoan parasites in Egypt. Parasitol Res 2013;112:595-601.

31. Efunshile MA, Ngwu BA, Kurtzhals JA, Sahar S, König B, Stensvold CR. Molecular detection of the carriage rate of four intestinal protozoa with real-time polymerase chain reaction: possible overdiagnosis of Entamoeba histolytica in Nigeria. Am J Trop Med Hyg 2015;93:257-62.

32. Krumkamp R, Sarpong N, Schwarz NG, Adlkofer J, Loag W, Eibach $\mathrm{D}$, et al. Gastrointestinal infections and diarrheal disease in Ghanaian infants and children: an outpatient case-control study. PLoS Negl Trop Dis 2015;9:e0003568.

33. Hachiya M, Kikuchi H, Mizoue T. Descriptive epidemiology of travel-associated diarrhea based on surveillance data at Narita International Airport. J Travel Med 2010;17:105-10. 
34. Lääveri T, Pakkanen SH, Kirveskari J, Kantele A. Travellers' diarrhoea: impact of TD definition and control group design on study results. Travel Med Infect Dis 2018;24:37-43.

35. Soonawala D, van Lieshout L, den Boer MA, Claas EC, Verweij JJ, Godkewitsch A, et al. Post-travel screening of asymptomatic longterm travelers to the tropics for intestinal parasites using molecular diagnostics. Am J Trop Med Hyg 2014;90:835-9.

36. ten Hove RJ, van Esbroeck M, Vervoort T, van den Ende J, van Lieshout L, Verweij JJ. Molecular diagnostics of intestinal parasites in returning travellers. Eur J Clin Microbiol Infect Dis 2009;28: 1045-53.

37. Robert-Koch-Institut. Steckbrief seltener und importierter Infektionskrankheiten. Cited 2020 July. Available from: https://edoc.rki. de/bitstream/handle/176904/3724/steckbriefe.pdf? sequence $=1$ \&isAllowed $=\mathrm{y}$.

38. European Center for Disease Prevention and Control. Giardiasis (lambliasis) - Annual Epidemiological Report for 2017. Cited July
2020, Available from: https://www.ecdc.europa.eu/en/publicationsdata/giardiasis-lambliasis-annual-epidemiological-report-2017.

39. Jelinek T, Peyerl G, Löscher T, von Sonnenburg F, Nothdurft HD. The role of Blastocystis hominis as a possible intestinal pathogen in travellers. J Infect 1997;35:63-6.

40. Kurt Ö, Doğruman Al F, Tanyüksel M. Eradication of Blastocystis in humans: really necessary for all? Parasitol Int 2016;65: 797-801.

41. Roberts T, Stark D, Harkness J, Ellis J. Update on the pathogenic potential and treatment options for Blastocystis sp. Gut Pathog 2014;6:17.

42. Shlim DR, Hoge CW, Rajah R, Rabold JG, Echeverria P. Is Blastocystis hominis a cause of diarrhea in travelers? A prospective controlled study in Nepal. Clin Infect Dis 1995;21:97-101.

43. Hamer DH. Multiplex PCR for determining aetiology of travellers' diarrhoea: too much information or too little? J Travel Med 2018; 25:1. 